\title{
Sewage sludges: Toxic substances, fertilizers, or secondary metal resources?
}

Sludges accumulate as waste products in sewage treatment plants, and they commonly contain elevated concentrations of organic pollutants and heavy and noble metals. The methods of sludge disposal include its use as fertilizer on agricultural land, ocean dumping, disposal in landfills and municipal garbage dumps, and high-temperature incineration and pyrolysis. As population and industrialization increase, the disposal of sewage sludges represents a growing political and environmental problem.

Future disposal efforts should concentrate on the vigorous control of pollutants at their sources and the development of environmentally and economically acceptable extraction processes for heavy and noble metals. The benefits would include the possible disposal of sewage sludges having reduced pollutant loads as fertilizers on agricultural land, revenues from the extraction of heavy and noble metals, savings of expensive waste repository space, conservation of primary geologic metal resources, and prevention of possible environmental impacts on continental and marine ecosystems.

\section{Introduction}

Sewage sludges are anaerobically digested or aerated end products of wastewater treatment and purification. They represent about 10 percent of municipal waste production (Forstner and others, 1991). These sludges are known for their nonbiodegradable and consequently persistent, potentially elevated contents of organic pollutants (for example, phenol, polychlorinated biphenyls, and phthalates) and of heavy metals and metalloids (for example, lead, cadmium, chromium, copper, nickel, zinc, mercury, arsenic, and selenium) (Lester, $1987 \mathrm{a}, \mathrm{b})$ (table 1).

Release of partially treated, or even untreated, municipal wastewaters and sewage sludges into continental and marine ecosystems may cause environmentally and politically unacceptable problems, including the contamination of water supplies, endemic diseases, offensive smell, eutrophication of lakes and rivers, and phytotoxicity and zootoxicity, along with subsequent possible effects to animal or human food chains. The problem is growing because of increasing population and industrialization, especially in the less developed countries.

Depending on the composition of the sewage sludges and on pertinent legislation, these sludges may be considered not only as toxic substances that require dumping in special waste repositories but also as high-quality fertilizers or very interesting secondary metal resources. This paper summarizes the environmental regulations for sewage sludge treatment and disposal, and it discusses the potential of sewage sludges as fertilizers and secondary metal resources.

\section{Sewage sludge disposal}

Sludge disposal methods include (1) its composting and use as fertilizer on agricultural land, (2) ocean dumping, (3) disposal in garbage dumps and landfills, and (4) incineration or pyrolysis and subsequent burial of slags and ashes in suitable waste repositories.

\section{Use as fertilizer}

Sludges from municipal sewage treatment works, mainly those from plants that remove phosphates from wastewater, are known to be very good phosphate fertilizer (Furrer, 1980, 1981; Häni, 1991). A considerable amount of sewage sludges is used as fertilizer on agricultural land; in Germany, this takes 35 percent of the annually accumulating sludges. For such use, several government authorities have set the maximum acceptable heavy metal concentrations in sewage sludge, maximum values for metals in sludges applied to land, and annual loadings of metals and total metal concentrations in sludge-amended soils (Lester, 1987a). Metals for which the maximum acceptable levels are set include cadmium, chromium, copper, mercury, nickel, lead, selenium, and zinc, and in some countries, maximum acceptable values have been given as well for organic pollutants. In order to define the importance of the problem, we should note that waste production and sewage sludges are not the most significant source of heavy metal soil pollution, but atmospheric deposition is. For example, in Germany, atmospheric deposition of the element cadmium is on the order of 90 tons ( $t$ ) per year, whereas sewage sludge contributes only $13 \mathrm{t}$ per year (Häni, 1991).

Table 1. - Typical heavy metal contents in sewage sludge [Units are in $\mathrm{mg} / \mathrm{kg}$ of dry matter; -, not significant]

\begin{tabular}{lccrr}
\hline Element & United States & Great Britain $^{1}$ & Sweden $^{1}$ & Italy $^{2}$ \\
\hline Lead & 1,380 & 820 & 281 & 210 \\
Cadmium & 74 & - & 13 & 2 \\
Chromium & 2,031 & 980 & 872 & 62 \\
Copper & 1,024 & 970 & 791 & 360 \\
Nickel & 371 & 510 & 121 & 42 \\
Zinc & 3,315 & 4,100 & 2,055 & 1,540 \\
Mercury & - & - & - & 4 \\
\hline
\end{tabular}

${ }^{1}$ Häni, 1991

${ }^{2}$ G. Morteani, unpublished data 
The maximum permissible concentrations for individual heavy metals in sewage sludges used as fertilizer differ by as much as 100 percent (see table 2). This clearly demonstrates that the behavior of heavy metals in soils, weathering profiles, ground-water aquifers, and plants is largely unknown. Insufficient also is the knowledge of the potential toxicity problems and bioaccumulation of heavy metals that arise in food chains from the application of sewage sludges to agricultural land. This uncertainty is highlighted by the very different maximum permissible heavy metal concentrations in sludge-amended soils, such as those given by German and Italian regulations (table 3 ).

\section{Ocean dumping}

For disposal of sewage sludges at sea, several countries have signed agreements called the Oslo Convention, Paris Convention, and London Convention, which regulate the dumping of waste into marine waters (Lester, 1987a). However, the declarations commonly have not been met by the signees, and wastewaters and sludges carrying pollutants continue to be released into the aquatic environment at ocean and shoreline outfalls. These pollutants subsequently accumulate in sediments and marine organisms.

Quantitative estimates for heavy metal accumulations in wastewaters have been performed for global, and for some local, metal releases to the environment. The ocean outfall systems for the southern Californian coast in the United States represent an extreme example for the waste of heavy metals into the hydrosphere. There, the combined annual discharge has been estimated at $1,022 \mathrm{t}$ of zinc, $539 \mathrm{t}$ of chromium, $402 \mathrm{t}$ of copper, $182 \mathrm{t}$ of nickel, $165 \mathrm{t}$ of lead, 22 $t$ of cadmium, and $20 t$ of silver (Galloway, 1979). Similar ocean outfall systems and associated metal releases are present in other parts of the world, as, for example, in Sydney, Australia. Global metal injections into the oceans and atmosphere from municipal sewage have been estimated to be $3,000 \mathrm{t}$ of cadmium, $55,000 \mathrm{t}$ of chromium, 42,000 t of copper, 15,000 $\mathrm{t}$ of lead, 440,000 $\mathrm{t}$ of iron, $7,400 \mathrm{t}$ of manganese, $17,000 \mathrm{t}$ of nickel, 2,300 $\mathrm{t}$ of silver, and 100,000 t of zinc each year (Galloway, 1979; Nriagu and Pacyna, 1988).

\section{Landfills}

As a result of the decreasing acceptance of the use of sewage sludges in agriculture, an increasing percentage of the sludges will be deposited in urban solid waste landfills or in "monolandfills," that is, landfills reserved entirely for sewage sludges. A landfill containing only sewage sludges represents a less complicated system than a municipal solid waste landfill, which generally holds a range of waste products (Lichtensteiger and others, 1987; Förstner and others, 1991). However, pollution cases associated with landfills have resuited in negative publicity, and the development of future waste disposal sites has become a major public issue.

\section{Incineration}

Incineration and pyrolysis of sewage sludges result in significant reductions in volume, and the main residues of incineration or pyrolysis of sewage sludges are the slags or the pyrolysis "peat." In both cases, heavy metals are highly immobile, so the slags are well suited for disposal in normal landfills (Förstner and others, 1991), or they can be used as road-building material (Vogg, 1991). However, a problem is posed by the fly ashes, which contain easily leachable heavy metals and also dioxins and furanes that are produced by reactions at temperatures between $250{ }^{\circ} \mathrm{C}$ and $450{ }^{\circ} \mathrm{C}$ (Vogg, 1991). Such ashes require disposal in special waste repositories.
Table 2.-Maximum heavy metal concentrations in sewage sludge that are considered permissible for use as agricultural fertilizer [Units are in $\mathrm{mg} / \mathrm{kg}$ of dry matter; -, not significant. Abbreviations: E.C., European Community]

\begin{tabular}{lrrrrr}
\hline Element & E.C. & $\begin{array}{r}\text { Germany } \\
1984^{1}\end{array}$ & $\begin{array}{c}\text { Germany } \\
1992\end{array}$ & Italy & Sweden $^{1}$ \\
\hline Lead & 1,000 & 1,200 & 900 & 750 & 300 \\
Cadmium & 40 & 20 & 10 & 20 & 15 \\
Chromium & - & 1,200 & 900 & 760 & 1,000 \\
Copper & 1,500 & 1,200 & 800 & 1,000 & 3,000 \\
Nickel & 400 & 200 & 200 & 300 & 500 \\
Zinc & 3,000 & 3,000 & 2,500 & 3,000 & 10,000 \\
\hline
\end{tabular}

${ }^{1}$ Häni, 1991

Table 3.-Maximum permissible heavy metal concentrations in sludge-amended soils

[Units are in $\mathrm{mg} / \mathrm{kg}$ of dry matter]

\begin{tabular}{lcr}
\hline Element & Germany & Italy \\
\hline Lead & 100 & 50 \\
Cadmium & 1.5 & 1 \\
Chromium & 100 & 53 \\
Copper & 60 & 50 \\
Nickel & 50 & 30 \\
Mercury & 1 & 10 \\
Zinc & 200 & 150 \\
\hline
\end{tabular}

\section{Sludges as secondary metal resources}

B ecause of the above-listed environmental concerns and the possible bioaccumulation of pollutants in food chains, sewage sludges are regarded mostly as waste products. However, sewage sludges show not only the high contents of heavy metals mentioned above, but they also possess important noble metal concentrations (gold and platinoids) in most of the examined cases (compare Furr and others, 1976; Mumma and others, 1983, 1984, 1988; Lottermoser, 1993). In particular, the gold contents of some sewage sludges are similar to, or even higher than, those of geologic ore deposits that are mined for gold.

\section{Heavy metals}

The total heavy metal content of sewage sludges is about 0.1 to 1 weight percent on a dry weight basis. Individual heavy metal contents are highly variable; however, zinc, lead, chromium, and copper are generally present in higher concentrations than are nickel, cadmium, and mercury (table 1).

Heavy metals appear in a variety of household products, such as cleaners, cosmetics, shampoos, and toothpastes, all products that are disposed of down the drain. Human excreta, industrial effluents, road-runoff water carrying traffic pollutants, rainwater, drinking water, corrosion from water-supply piping systems, and ground water infiltrating into sewage piping all contribute to the heavy metal contents in wastewaters and sewage sludges. The concentration of heavy metals in sludges varies according to the type of wastewater treatment, the presence of specific metal-processing industries in the area. the lifestyle of the population, the road-runoff contamination, and the state of the drinking water supply systems. 


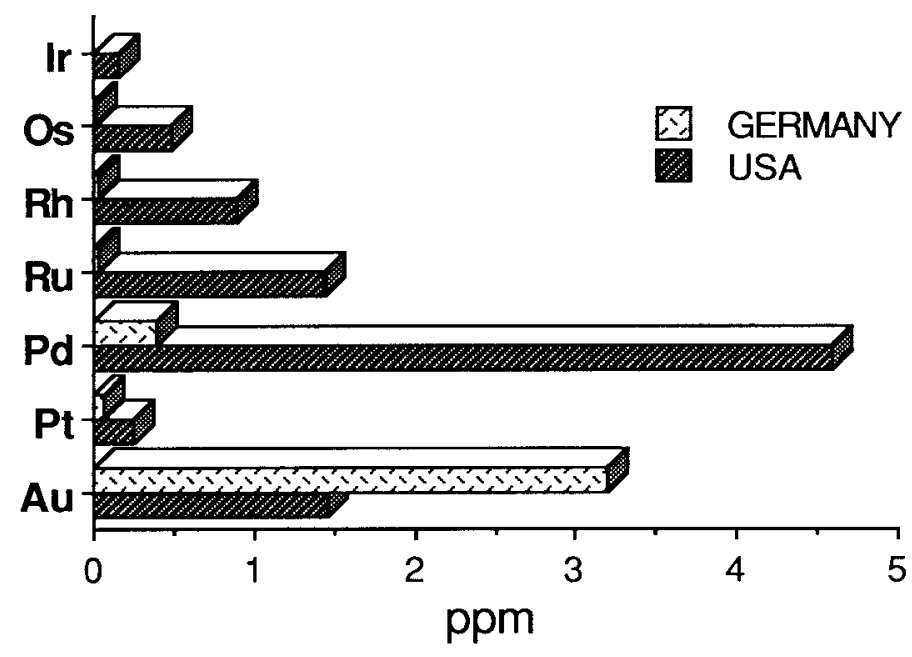

Figure 1.-Average noble metal contents of municipal sewage sludges. Data refer to dried sewage sludge matter and were taken from Furr and others (1976), Mumma and others (1983, 1984, 1988), and Lottermoser (1993). Abbreviations: Ir, iridium; Os, osmium; Rh, rhodium; Ru, ruthenium; Pd, palladium; Pt, platinum; Au, gold; ppm, parts per million.

Heavy metals within wastewaters are found as dissolved, colloidal, and solid species. Partitioning of dissolved metals onto solid particles in municipal sewers, especially during wastewater treatment, takes place by a number of chemical and biochemical mechanisms, including binding to extracellular polymers; active metabolic intracellular uptake of soluble metals by bacteria; absorption by bacterial cells, organic particles, and clays; and formation of insoluble hydroxides, carbonates, phosphates, sulfates, and sulfides (see Cheremisinoff, 1989). Subsequent physical entrapment of the heavy metal precipitate may take place in the biofloc of wastewater treatment plants.

\section{Noble metals}

Sewage sludges commonly possess high noble metal contents, including gold and palladium values within the parts per million (ppm) range (table 4). Some exceptionally high precious metal concentrations also have been reported for individual sewage sludges (for example, $56 \mathrm{ppm}$ of gold, Lottermoser, 1993). Lower concentrations generally have been detected for platinum, ruthenium, rhodium, osmium, and iridium (table 4, fig. 1).

The highest noble metal contents have been determined in sludges accumulating in cities that have a pronounced jewelry industry. Elevated noble metal values also can be expected in sludges produced in localities of recent and ancient noble mining activities (for example, Bendigo and Ballarat in Australia). All sewage sludges possess higher palladium than platinum values. The palladium to platinum ratio in sludges in the United States is about 11 , and in German ones, it is 4.5 (fig. 1). The crustal palladium to platinum ratio is only 1.5 . This strong palladium enrichment is likely the result of platinoid differentiation during transport in municipal sewer systems and the subsequent preferential deposition of palladium onto organic-rich material, a feature that commonly is observed in analogous geologic environments. High palladium sludges will get particular economic interest if the palladium-based exhaust catalysts developed by the Japanese National Institute for Resources and Environment prove to be successful (Anonymous, 1992).
Table 4.-Range of noble metal contents of municipal sewage sludges in the United States and the Federal Republic of Germany

[Units are in $\mathrm{mg} / \mathrm{kg}$ of dry matter; numbers in parentheses show numbers of samples. Data were taken from Furr and others (1976), Mumma and others (1983, 1984, 1988), and Lottermoser (1993)]

\begin{tabular}{lrrrrrr}
\hline & \multicolumn{3}{c}{ USA } & \multicolumn{3}{c}{ Germany } \\
\hline & Minimum & \multicolumn{1}{c}{ Maximum } & \multicolumn{3}{c}{ Minimum } & Maximum \\
\hline Gold & 0.08 & 12.90 & $(87)$ & 0.28 & 56.00 & $(26)$ \\
Platinum & .05 & .74 & $(15)$ & $<.01$ & 1.07 & $(26)$ \\
Palladium & .23 & 16.20 & $(44)$ & .04 & 4.70 & $(26)$ \\
Ruthenium & .05 & 7.05 & $(44)$ & $<.01$ & .39 & $(13)$ \\
Rhodium & .08 & 2.70 & $(31)$ & $<.01$ & .35 & $(13)$ \\
Osmium & .06 & 3.18 & $(15)$ & $<.01$ & .05 & $(13)$ \\
Iridium & .05 & .46 & $(15)$ & $<.01$ & .03 & $(13)$ \\
\hline
\end{tabular}

Possible sources of noble metals in sewage sludges include industrial discharges (for example, dental surgeries, jewelry industry), domestic additions (for example, abrasion of jewelry), automobile emission control systems (platinoid-bearing catalysts), and to a lesser degree, background concentrations within domestic water supplies, surface-runoff water, sewer infiltration water, and corrosion of water pipes (Lottermoser, 1993). Human excreta have low gold and platinum contents, and they account to an insignificant degree (approximately 0.01 percent) for high noble metal values in sewage sludges (Lottermoser, 1993).

Transport of these metals within sewer systems possibly takes place as solid particles (from industrial sources and dental surgeries), as absorbed elements on suspended particulate matter, as colloids, and as dissolved organic and inorganic complexes. Most of the gold in mechanically treated wastewaters appears to be associated with micrometer-sized suspended particles, and to a lesser degree, the gold is present as a dissolved species (Kim and others, 1982).

Furr and others (1976) proposed that the elevated gold content of the sewage sludges of San Francisco, California, USA (7 ppm $\mathrm{Au}$ ), is a result of gold-enriched waters from the watershed area of the city. However, natural waters are capable of transporting only very low concentrations of noble metals, and hence, the gold and platinoid enrichment of sewage sludges cannot be due simply to goldand platinoid-enriched natural waters.

Precipitation caused by microbiological activity, reactions with organic matter, decreases in the ligand concentration (sulfur), and absorption onto sulfides and organic material are likely to be responsible for the rapid and efficient concentration of gold and platinoids onto organic sewage particles in municipal wastewater systems. The precipitation and enrichment processes in the sewers must take place rapidly, as wastewaters generally need only a few hours to reach the treatment works. Similar to the genesis of hydrothermal gold deposits, the destabilization of gold and platinoid complexes and colloids from large wastewater volumes having low contents of the noble metals (parts per thousand to parts per billion levels) could be responsible for the accumulation of relatively high noble metal concentrations (parts per billion to parts per million levels) in the solid matter of sewage sludges.

Quantitative estimates of gold, platinum, and palladium masses accumulating in sludges of the industrialized countries have been obtained as follows (see Bowen, 1985): Sludge production has been estimated at 180 grams of dry matter per person per day. If we assume a world population of 5 billion, of which 25 percent is industrialized and has municipal sewer systems and sewage treatment works, the production of dry sludge amounts to approximately 82 
million t per annum (Bowen, 1985). Mean noble metal contents have been calculated from published analyses as $1.85 \mathrm{ppm}$ gold, $0.13 \mathrm{ppm}$ platinum, and $3.03 \mathrm{ppm}$ palladium. These estimates likely are too high because of the limited number of analyses (gold, 113 analyses; platinum, 41 analyses; and palladium, 70 analyses; Furr and others, 1976; Mumma and others, 1983, 1984, 1988; Lottermoser, 1993). Thus, for conservative estimates, the mean contents have been assumed to be $1.25 \mathrm{ppm}$ gold, $0.10 \mathrm{ppm}$ platinum, and $1.00 \mathrm{ppm}$ palladium. Such average noble metal contents would imply that approximately $100 \mathrm{t}$ of gold, $8 \mathrm{t}$ of platinum, and $80 \mathrm{t}$ of palladium are accumulating in sewage sludges each year. In comparison, the annual global metal production from geologic ores amounts to more than $1,653 \mathrm{t}$ of gold, $100 \mathrm{t}$ of platinum, and $100 \mathrm{t}$ of palladium (Murray, 1990; Bachmann, 1990).

\section{Metal recovery from sewage sludges}

Metals of geologic ores are mined, extracted, and used for industrial products, whereas metals in sewage are wasted, dumped on land or at sea, or even released to the environment. Recycling of metals conserves primary geologic resources, and in some cases including sewage sludges, it would avoid the uncontrolled release of metals into the environment. Metals can be, and are, recycled, and this secondary industry is of increasing importance in the developed countries.

A noble metal ore that requires no mine, no explosives, no crushing, and no trucking, that averages values of parts per million of gold and palladium, whose annual worldwide production amounts to approximately $100 \mathrm{t}$ of gold and $80 \mathrm{t}$ of palladium, and whose production is secured as long as the human race exists, this represents an "attractive ore."

The extraction of noble metals from sludges can be justified as an environmentally acceptable process, but the economic potential for the development of a viable extraction method also is considerable. The disposal of $1 \mathrm{t}$ of sewage sludge that has metal contents above land-application limits (sludge that cannot be used for agricultural purposes) costs at the moment in Germany about DM250-500. The prices for dumping are supposed to increase at a rate of DM25-50 each year. In contrast, $1 \mathrm{t}$ of waste to be treated by composting costs only DM30. Thus, the extraction of metals from sewage sludges would be repaid not only by the value of the metal but also by the costs that would be saved for the disposal of the sludges in waste repositories. In addition, decontaminated sludges having reduced pollutant loads could be disposed of as fertilizer on agricultural land, and the existing and potential environmental problems could be addressed before they cause toxicity symptoms in plants, animals, and humans.

Several methods have been under investigation for the removal of metal and phosphorus from sewage sludges and incinerated ashes (for example, see Scott and Horlings, 1975; Oliver and Carey, 1976; Markels, 1977; Krofchak, 1979; Tyagi and Couillard, 1987; Tyagi and others, 1988). These methods include hydrometallurgical extraction and bacterial leaching. However, one should remember that the current metal-extraction techniques do not reduce the concentrations of organic pollutants. A reduction in the organic pollutant loads may be achieved only by vigorous control of the sources of industrial effluents.

Base metals can be removed from sewage sludges by acidifying the sludges by the use of mineral acids. However, acidification is associated with the consumption of large amounts of acid, and at the end of the treatment, a large amount of lime is needed in order to raise the $\mathrm{pH}$ of the sludge to neutral. Although good metal removal can be achieved in some cases, the economical and operational constraints have made the practical application of these methods unattractive.
In anaerobically digested sewage sludges, most base metals exist in the reduced and insoluble sulfide form. Bacterial leaching causes oxidation of the insoluble metal sulfides to the soluble metal sulfates. Thus, bacterial leaching has been used to extract metal from anaerobically digested sludges (for example, see Tyagi and Couillard, 1987; Tyagi and others, 1988). Currently, bacterial leaching is used to extract copper and uranium from low-grade ores in industrial heap, dump, and in-place leaching processes. The major advantage of bacterial leaching over acid extraction is that good metal removal can be achieved along with a low requirement for acid (Tyagi and Couillard, 1987; Tyagi and others, 1988). Similarly, the requirement for lime to neutralize the sludges is reduced. In addition, the treated sludges are easy to filter, the sludge nutrients are not diminished, hydrogen sulfide is not released, and the decontaminated sludges produce less odor (Tyagi and Couillard, 1987; Tyagi and others, 1988).

The extraction of noble metals from sewage sludges is possible through the use of cyanide solutions (compare Markels, 1977; Krofchak, 1979; and Whiteway, 1986). A Canadian mining company has been involved in the recovery of gold from sewage-sludge ashes of the city of Toronto by using cyanide-extraction techniques (Whiteway, 1986). The effectivity, that is, the extraction rate of hydrometallurgical techniques, is dependent on the reaction time, temperature, leaching agent concentration, and $\mathrm{pH}$ conditions. The possible lixiviation agents for gold are cyanide, thiourea, thiosulfate, polysulfide, chlorine, or organic bromine complexes. Some of these agents are not selective and also form complexes with sulfides and other metals. This results in high reagent consumption and low recoveries. In addition, major health and environmental problems are associated with the cyanide and organic bromine processes.

No satisfying process seems to exist today for the extraction of heavy and (or) noble metals. Therefore, major research efforts are necessary - and will be worthwhile - for achieving the extraction of metals from sewage sludges.

\section{Conclusions}

Municipal wastewaters and sewage sludges contain large amounts of heavy and noble metals. However, none of these metals are being extracted now from the sludges, and metals continue to be released into the environment or literally are wasted in garbage dumps or incinerated-ash repositories. Our "effluent" societies cannot afford to waste raw materials, and sewage sludge should not be regarded as waste but as a secondary resource for metals and nutrients for plant growth.

Investigations by geoscientists could add significantly to the knowledge on the sources, transport, deposition, concentration, and speciation of heavy and noble metals in municipal wastewater systems and sewage sludges. Ore deposit geologists are confronted by challenging research opportunities. For example, anthropogenic noble metal deposits are being formed now in areas of ocean-outfall systems, such as that of Athens, Greece, and these metal accumulations may be analogous to the ancient black-shale noble metal deposits. However, the noble metal sources, transport ligands, and precipitation and enrichment mechanisms that are responsible for the high values in sewage sludges remain largely speculative; the positions of noble metals in the sludges are still unknown; and the reasons for the pronounced differences in platinoid distribution in sludges from the United States and Germany have yet to be found, true challenges for the future. 


\section{References}

Anonymous, 1992, Platin: Erzmetall, v. 45, no. 11, p. 556.

Bachmann, H.-G., 1990, Precious metals in and for new technologies, in Kürsten, M., ed., Raw materials for new technologies, International Symposium, 5th, Hannover, Germany, 1988, Proceedings: Stuttgart, E. Schweizerbart'sche Verlagsbuchhandlung, p. 61-70.

Bowen, H.J.M., 1985, The cycles of copper, silver and gold, in Hutzinger, O., ed., The natural environment and the biogeochemical cycles, in the collection The handbook of environmental chemistry: Berlin, SpringerVerlag. v. 1, part D, p. 1-27.

Cheremisinoff, P.N., ed., 1989, Wastewater treatment technology, volume 3 of Encyclopedia of environmental control technology: Houston. Texas, USA, Gulf Publishing Company, 684 p.

Förstner, U., Colombi, C., and Kistler, R., 1991, Dumping of wastes, in Merian, E., ed., Metals and their compounds in the environment: Weinheim, VCH Verlagsgesellschaft, p. 334-355.

Furr, A.K., Lawrence, A.W., Tong, S.S.C., Grandolfo, M.C., Hofstader, R.A., Bache, C.A., Gutenmann, W.H., and Lisk, D.J., 1976, Multielement and chlorinated hydrocarbon analysis of municipal sewage sludges of American cities: Environmental Science and Technology, v. 10, no. 7 , p. 683-687.

Furrer, O.J., 1980, Landwirtschaftlicher Wert des Klärschlamms: EAS Seminar, Basel, Switzerland, p. 24-28.

1981, Siedlungskomposte in der Schweiz-positive und negative Aspekte: 17th Vortragstagung, Deutsche Gesellschaft für Qualitätsforschung, Speyer, Germany, 26-27 März.

Galloway, J.N., 1979, Alteration of trace metal geochemical cycles due to the marine discharge of wastewater: Geochimica et Cosmochimica Acta, v. 43 , no. 2 , p. $207-218$.

Häni, H., 1991, Heavy metals in sewage sludge and town waste compost, in Merian, E., ed., Metals and their compounds in the environment: Weinheim, VCH Verlagsgesellschaft, p. 357-368.

Kim, J.I., Lux, D., and Fiedler, I., 1982, Multielement trace analysis for inorganic species in large-volume water samples by mono-standard neutron-activation analysis: Mikrochimica Acta, part 1, p. 137-153.

Krofchak, D., 1979, Process for the treatment of incinerated sewage sludge ash: European Patent 0,004,778.

Lester, J.N., ed., 1987a, Sources, analysis, and legislation, volume 1 of Heavy metals in wastewater and sludge treatment processes: Boca Raton, Florida, USA, CRC Press, 183 p.

1987b, Treatment and disposal, volume 2 of Heavy metals in wastewater and sludge treatment processes: Boca Raton, Florida, USA, CRC Press, $155 \mathrm{p}$.

Lichtensteiger, T., Brunner, P.H., and Langmeier, M., 1987, EWAG-Project Nr. 30-681, Klärschlamm in Deponien: Cost 681-Forschungsprojekt.

Lottermoser, B.G., 1993, Gold and platinoids in municipal sewage sludges: Environmental Science and Technology, submitted.

Markels, M., Jr., 1977, Process for the recovery of selected metal values from waste waters: U.S. Patent 4,033,763.

Mumma, R.O., Rashid, K.A., Raupach, D.C., Shane, B.S., Scarlet-Kranz, J.M., Bache, C.A., Gutenmann, W.H., and Lisk, D.J., 1988, Mutagens, toxicants, and other constituents in small city sludges in New York State: Archives of Environmental Contamination and Toxicology, v. 17, no. 5, p. $657-663$.

Mumma, R.O., Raupach, D.C., Waldman, J.P., Hotchkiss, J.H., Gutenmann, W.H., Bache, C.A., and Lisk, D.J., 1983, Analytical survey of elements and other constituents in central New York State sewage sludges: Archives of Environmental Contamination and Toxicology, v. 12, no. 5 , p. $581-587$.

Mumma, R.O., Raupach, D.C., Waldman, J.P., Tong, S.S.C., Jacobs, M.L., Babish, J.G., Hotchkiss, J.H., Wszolek, P.C., Gutenman, W.H., Bache, C.A., and Lisk, D.J., 1984, National survey of elements and other constituents in municipal sewage sludges: Archives of Environmental Contamination and Toxicology, v. 13, no. 1, p. 75-83.

Murray, Stewart, 1990, Gold, in Metals and Minerals Annual Review: London, Mining Journal, p. 9-15.

Nriagu, J.O., and Pacyna, J.M., 1988, Quantitative assessment of worldwide contamination of air, water and soils by trace metals: Nature (London), v. 333 , no. 6169 , p. $134-139$.
Oliver, B.G., and Carey, J.H., 1976, Acid solubilization of sewage sludge and ash constituents for possible recovery: Water Research, v. 10, no. 12, p. $1077-1081$.

Scott, D.S., and Horlings, H., 1975, Removal of phosphates and metals from sewage sludges: Environmental Science and Technology, v. 9, no. 9, p. 849-855.

Tyagi, R.D., and Couillard, D., 1987, Bacterial leaching of metals from digested sewage sludge: Process Biochemistry, v. 22, no. 4, p. 114-117.

Tyagi, R.D., Couillard, D., and Tran, F.T., 1988, Heavy metals removal from anaerobically digested sludge by chemical and microbiological methods: Environmental Pollution, v. 50, no. 4, p. 295-316.

Vogg, H., 1991, Abfallverbrennung-Fakten und Perspektiven: De Arbeitgeber, v. 22 , p. $870-873$.

Whiteway, P., 1986, Lasir to recover gold from Toronto's sewage: The Northern Miner Magazine, January, p. 1-2. $\square$

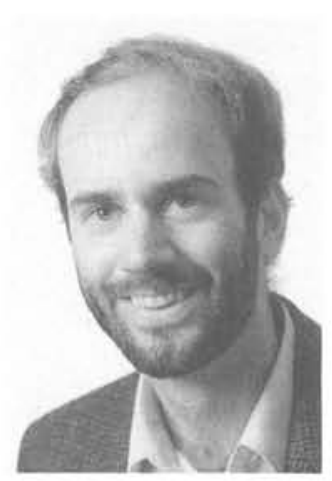

Dr. B.G. Lottermoser, born in 1961 , studied geology in Germany and Australia. He worked as an exploration geologist/consulting mineralogist in the mining industry, published over 25 scientific papers on mineralogy, ore deposit geology, and environmental geochemistry, and is a postdoctoral fellow at the School of Earth Sciences, The University of Melbourne, Parkville 3052, Australia.

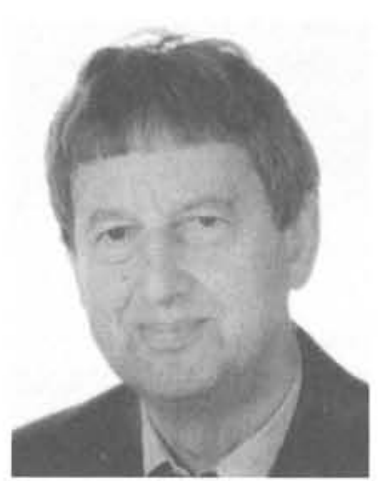

Dr. G. Morteani born in 1935, studied mining engineering and geology. He is currently professor for applied mineralogy and geochemistry at the Technical University of München (Germany) and author of more than 150 scientific papers in petrology, geochemistry, and mining geology. 